\title{
Editorials \\ Academic psychiatry and the pharmaceutical industry: \\ useful partnership or dangerous interaction?
}

\author{
Editoriali
}

Ricerca scientifica e interesse industriale:

accoppiata vincente o pericolosa connivenza?

\author{
CORRADO BARBUI, Guest Editor \\ and MICHELE TANSELLA, Editor
}

The relationship between academia and the pharmaceutical industry has long been considered a crucial subject in the field of clinical psychopharmacology. In the present issue of Epidemiologia e Psichiatria Sociale three Editorials and one Special Article discuss how this relationship has been influencing the production of scientific literature, its dissemination among psychiatrists and the wider society, and its impact on the everyday practice of medicine.

A common position emerging from all these contributions is that the problem is not disclosure of conflicting interests. The Special Article written by David Healy provides us with the example of guideline production (Healy, 2007). Guidelines for schizophrenia and for bipolar disorder that have been drawn up by experts funded by industry do not differ from independent guidelines (Pilling \& Price, 2006). So, if conflicting interests are not that relevant, where is the problem? The four contributions help us here. The Editorial written by Mauricio Tohen goes directly into the heart of the matter by highlighting that the value of research findings should be built upon the strength of the methodology (Tohen, 2007). Consequently, the scientific community should focus on improving and implementing methodologies to avoid bias. Unfortunately, bias is a colossal problem in the field of clinical psychopharmacology, as shown by Joanna Moncrieff and David Healy, who emphasised a second reason for concern, namely that drug companies control the production of the scientific literature (Moncrieff, 2007; Healy, 2007). Further, the contribution by Clive Adams adds the risk of being seduced by interpretations of the scientific literature that are not entirely based on a rigorous and critical appraisal of the available evidence: "the data were always there to be seen" (Adams \& Jayaram, 2007).
La relazione tra produzione di conoscenze scientifiche e interessi industriali è oggetto, ormai da molto tempo, di grande interesse, attenzione e preoccupazione. Per questo motivo Epidemiologia e Psichiatria Sociale ospita tre Editoriali e uno Special Article che discutono come, in ambito psicofarmacologico, tale relazione sembri influenzare in maniera sempre più pervasiva la produzione di ricerca scientifica, la diffusione di informazioni scientifiche presso gli operatori della salute mentale e il pubblico e, infine, le abitudini prescrittive in vigore nella pratica clinica quotidiana.

Un aspetto interessante che emerge dai quattro contributi si riferisce al fatto che la questione centrale non sembra essere il tanto chiacchierato conflitto di interessi degli autori di articoli scientifici e la necessità di una maggiore trasparenza nella sua esplicitazione. Il contributo di David Healy, che fornisce un esempio lampante della irrilevanza di questa questione, cita le linee guida sul trattamento farmacologico della schizofrenia e del disturbo bipolare (Pilling \& Price, 2006): le indicazioni che si trovano nelle linee-guida sponsorizzate dalla industria farmaceutica sono pressoché sovrapponibili a quelle prodotte da organismi indipendenti (Healy, 2007). E allora qual è il problema? Il contributo di Mauricio Tohen mette il dito nella piaga affermando chiaramente che il giudizio sulla bontà degli articoli scientifici deve tenere in considerazione il valore scientifico e metodologico del lavoro più che l'affiliazione degli autori (Tohen, 2007). Secondo Tohen, quindi, il problema è quello di migliorare la qualità della ricerca scientifica in psicofarmacologia clinica. Aspetto centrale, come ci esemplificano magistralmente i contributi di Joanna Moncrieff e David Healy che dimostrano come lo standard della ricerca in psicofarmacologia clinica sia miseramente scadente, con una continua e sistematica distorsione (bias) nella produzione di conoscenze scientifiche (Moncrieff, 2007; Healy, 2007). In aggiunta, 
Action is therefore required. First, strategies to decrease the risk of bias in the production of scientific knowledge should be implemented. It should be noted, at this regard, that the current standard of clinical studies is just a reflection of rules and requirements issued by regulatory agencies for drug approval and marketing. If we call for a change in clinical studies, a change in regulatory systems has first to be implemented (Barbui \& Garattini, 2007). For example, in Europe new drugs can be evaluated with no comparison with active alternative treatments. As a consequence of this rule, Phase III studies compare new drugs with placebo to make these new drugs eligible for registration. If comparisons are made, Phase III studies usually rely on demonstrating therapeutic "non-inferiority", because this is in agreement with current requirements. However, if there is broad scientific consensus that active-control superiority clinical trials should be designed and powered to generate evidence of superiority between competing treatments, then this should be reflected in pharmaceutical legislation. Similarly, other positive changes in terms of trial design, analysis and reporting will probably be achieved only if they are a requirement of new legislation.

A second aspect is data accessibility. Given the importance of publication bias, there should be a global initiative that aims to make all trial data accessible to organisations involved in research synthesis (Barbui \& Cipriani, 2007). Regulatory authorities should require, before reviewing applications for the licensing of new drugs, a statement in which the applicant agrees that all data must be accessible to specific organisations involved in research synthesis, and that accessibility will be preserved for a minimum number of years. Scientific journals could adopt a similar stance, requiring that agreement before accepting reports of clinical trials. JAMA (Journal of the American Medical Association) has already successfully implemented a policy requiring an independent statistical analysis for industry-sponsored studies. There is no reason why a similar policy should not be implemented on such an important issue as data accessibility.

Third, the development of studies that escape the control of drug companies (independent studies) should be facilitated at the national level. In Italy a Ministerial Decree was issued in 2004 recognising the need for establishing rules to help implement independent clinical trials (Tognoni \& Franzosi, 2005). In essence, the Decree states that if a set of conditions are met: the study coordinating centre is independent of drug company support; study results can be disseminated autonomously; there is la produzione di conoscenze scientifiche è pressoché interamente controllata e influenzata dalla industria farmaceutica. Clive Adams aggiunge, infine, i rischi di distorsione a livello di interpretazione dei dati a nostra disposizione (Adams \& Jayaram, 2007). Abbiamo quindi due problemi maggiori: migliorare la qualità della ricerca in psicofarmacologia clinica cercando di limitare al massimo il rischio di bias e stimolare la produzione di conoscenze scientifiche che sfuggano al controllo dell'industria farmaceutica (studi indipendenti).

Rispetto alla prima questione, è chiaro che lo standard corrente delle sperimentazioni in psicofarmacologia clinica non fa altro che rispecchiare le norme in vigore attualmente in Europa in materia di approvazione e commercializzazione dei medicinali. Se la comunità scientifica ritiene che la metodologia delle sperimentazioni debba evolversi e modificarsi, è necessario che queste modifiche ed evoluzioni siano parte di una nuova legislazione europea sulla commercializzazione dei farmaci (Barbui \& Garattini, 2007). Per esempio, attualmente la legislazione prevede che, per essere commercializzato, un nuovo farmaco debba essere più efficace del placebo. Di conseguenza, gli studi registrativi in psicofarmacologia clinica confrontano i nuovi psicofarmaci con il placebo. Se la comunità scientifica ritiene che questo non sia metodologicamente corretto in un ambito della medicina in cui vi sono trattamenti farmacologici di provata efficacia, e che sia necessario confrontare i nuovi farmaci con quelli già in commercio al fine di evidenziare un valore aggiuntivo (in termini di efficacia o tollerabilità, anche in sottogruppi di pazienti) per ogni nuovo farmaco che venga immesso sul mercato, allora questo bisogno andrebbe riconosciuto dalla legislazione europea, che andrebbe modificata di conseguenza. Vi sono bias legati al disegno delle sperimentazioni, alla analisi dei dati e al modo in cui $i$ dati vengono presentati che potrebbero essere ridotti o eliminati se la legislazione europea fosse più attenta a questi aspetti metodologici.

Un secondo aspetto è la accessibilità dei dati, o meglio l'inaccessibilità dei dati delle sperimentazioni. Questo fenomeno è noto come bias legato alla pubblicazione, e si riferisce al fatto che solo alcuni studi vengono resi pubblici. In aggiunta, molto spesso i dati originali degli studi resi pubblici (per esempio pubblicati sulle riviste scientifiche) non sono accessibili. Questo non va bene e andrebbe modificato (Barbui \& Cipriani, 2007). Le autorità regolatorie dovrebbero richiedere, prima di approvare la commercializzazione di un nuovo farmaco, l'accordo da parte della industria farmaceutica a rendere accessibili tutti i dati che si riferiscono al nuovo farmaco per un determinato numero di anni. Altrimenti il nuovo farmaco non viene approvato. Analogamente, le riviste scientifiche devono adottare rego- 
no personal financial interest in studying the drugs included in the trial; the study drugs are licensed for the indication to be investigated, then the National Health Service (NHS) supports the conduct of the trial in three ways: drug costs are paid by the NHS; there are no fees for submitting the study protocol to the local Ethics Committees; continuing medical education credits are provided to local investigators. It is too early to assess the impact of this Decree on the conduct of clinical research, but surely it represents a significant advance from a cultural viewpoint.

Setting new regulatory rules that may help avoid bias in the production of scientific knowledge, making trial data accessible, and supporting studies that escape the control of drug companies must be considered top priorities for people involved in evidence-based clinical psychopharmacology.

\section{REFERENCES}

Adams C. \& Jayaram M. (2007). Do findings from new trials for schizophrenia fit with existing evidence: not duped just beguiled? Epidemiologia e Psichiatria Sociale 16, 199-202.

Barbui C. \& Cipriani A. (2007). Evidence-based psychopharmacology: an agenda for the future. Evidence Based Mental Health 10, 4-6.

Barbui C. \& Garattini S. (2007). Regulatory policies on medicines for psychiatric disorders: is Europe on target? British Journal of Psychiatry 190, 91-93.

Healy D. (2007). The engineers of human souls \& academia Epidemiologia e Psichiatria Sociale 16, 205-211.

Moncrieff J. (2007). Co-opting psychiatry: the alliance between academic psychiatry and the pharmaceutical industry. Epidemiologia $e$ Psichiatria Sociale 16, 192-196.

Pilling S. \& Price K. (2006). Developing and implementing clinical guidelines: lessons from the NICE Schizophrenia Guideline. Epidemiologia e Psichiatria Sociale 15, 109-116.

Tognoni G. \& Franzosi M.G. (2005). [Experimenting in Italy: from GISSI to the Ministerial Decree]. Recenti Progressi in Medicina 96, 92 94.

Tohen M. (2007). Collaborations between academic psychiatry and the pharmaceutical industry: A perspective from industry. Epidemiologia e Psichiatria Sociale 16, 197-198. le analoghe, per esempio accettare per la pubblicazione i risultati delle sperimentazioni solo a patto che gli sperimentatori rendano accessibili i dati originali. La rivista americana JAMA (Journal of the American Medical Association) ha già adottato la politica di accettare per la pubblicazione solo le sperimentazioni sponsorizzate in cui uno statistico indipendente abbia analizzato $i$ dati confermando i risultati prodotti dallo statistico della industria farmaceutica.

Infine, per quanto riguarda la necessità di stimolare la produzione di conoscenze scientifiche che sfuggano al controllo dell'industria farmaceutica (studi indipendenti) vale la pena ricordare che l'Italia è dotata di una legislazione innovativa al riguardo (Tognoni \& Franzosi, 2005). Un Decreto Ministeriale promulgato nel 2004 ha infatti stabilito una serie di agevolazioni per le sperimentazioni finalizzate al miglioramento della pratica clinica e condotte non a fini di lucro. In sintesi, se una sperimentazione soddisfa i seguenti criteri: il promotore della sperimentazione è una istituzione pubblica o di natura non a fini di lucro; è previsto che la proprietà dei dati relativi alla sperimentazione, alla sua esecuzione, ai suoi risultati appartengano al promotore della stessa; è previsto che i risultati della sperimentazione siano pubblicati per decisione autonoma del promotore; la sperimentazione non è finalizzata allo sviluppo industriale del farmaco o comunque ai fini di lucro; i farmaci oggetto della sperimentazioni sono già in commercio e vengono sperimentati nella indicazione registrata, ebbene se queste condizioni sono soddisfatte il Decreto Ministeriale prevede una serie di agevolazioni per lo studio, tra cui: il costo dei farmaci rimane a carico del Sistema Sanitario Nazionale, non vi sono costi per istruire le pratiche ai Comitati Etici, sono previsti crediti per i medici partecipanti secondo l'idea che collaborare ad una sperimentazione è di per sé un evento formativo. È chiaro che l'impatto di questo decreto sullo stimolare nuove sperimentazioni indipendenti potrà essere giudicato solo a lungo termine, certamente tuttavia si tratta di un notevole passo in avanti dal punto di vista culturale.

Migliorare la qualità della ricerca clinica in psicofarmacologia clinica cercando di limitare al massimo il rischio di bias, rendere i dati delle sperimentazioni accessibili e stimolare la produzione di conoscenze scientifiche che sfuggano al controllo dell'industria farmaceutica sono priorità assolute per tutti gli operatori della salute mentale interessati a promuovere un utilizzo degli psicofarmaci davvero basato sulle prove di efficacia. 